\title{
Thrips (Thysanoptera, Insecta) of the Asteraceae family plants occurring in areas with different levels of anthropopressure in Lublin (Eastern Poland)
}

\section{Wciornastki (Thysanoptera, Insecta) zebrane z miejsc o różnym stopniu antropopresji w Lublinie na roślinach z rodziny Asteraceae}

\footnotetext{
* Dr Katarzyna Czepiel-Mil, dr Danuta Kowalczyk-Pecka, Department of Zoology, Ecology and Wildlife Management, University of Life Science in Lublin, Akademicka 13 St, 20-950 Lublin, phone: 081/4456062; e-mail: kasiamil.mil@gmail.com; danakp@wp.pl
}

Keywords: Thysanoptera, thrips, urban environment, Asteraceae, anthropopressure, hemeroby Słowa kluczowe: wciornastki, środowisko miejskie, Asteraceae, antropopresja, hemerobia

\section{Abstract}

In the years 2001-2003, a study on thrips (Thysanoptera) was conducted in Lublin (south-eastern Poland). The aim of the research was to determine the species composition of the insects on selected plants from the Asteraceae family collected at sights of varying anthropopressures in Lublin. Fifteen designated sites, classified as semi-natural and anthropogenic, were located in different parts of the city. As a result of the study, the occurrence of 36 thrips species was recorded. The species dominating in the whole material were: Thrips physapus, Thrips trehernei, Thrips validus and Frankliniella intonsa. The greatest thrips species variety was characteristic of the following plant species: Hieracium umbellatum, Matricaria perforata, Taraxacum officinale, Erigeron strigosus. The research conducted shows that urban environment is quite rich in terms of thrips species diversity. The number of species caught indicates their tolerance to moderately adverse conditions in the city. The most important factor affecting the number of collected species is plant diversity. The sites of different levels of athropopressure varied both in their species composition and in the number of thrips found.

๑) IOŚ-PIB

\section{INTRODUCTION}

Considerable alterations of abiotic conditions in towns lead to changes in their flora. They are caused by direct human activity, or indirectly by climatic changes, by soil and water degradation [Jackowiak 1990], which does not remain without an impact on herbivorous insects.

Thrips are a group of insects of varying sites and food preferences. The most numerous amongst them are herbivores feeding on juices of cultivated and wild plants. Thrips most often occur on flowers. Most species fly from place to place [Zawirska 1994].

Due to their tiny sizes $(1-3 \mathrm{~mm})$, most thrips are frequently overlooked in environmental monitoring research [Kucharczyk 2004] even though they can be indicators of air quality in urban areas [Vasiliu-Oromulu et al. 2008]

The first studies of thrips species composition in Lublin were conducted in the 1960s and 1970s by Sęczkowska and Gawarecka

\section{Streszczenie}

W latach 2001-2003 prowadzono badania nad wciornastkami (Thysanoptera) w Lublinie (południowo-wschodnia Polska). Celem pracy było poznanie składu gatunkowego tych owadów na wybranych roślinach z rodziny złożonych (Asteraceae), zbieranych z miejsc o różnym stopniu antropopresji w Lublinie. Wyznaczono 15 stanowisk położonych w różnych częściach miasta, które zaliczono do półnaturalnych oraz antropogenicznych. W wyniku badań stwierdzono występowanie 36 gatunków wciornastków. W całym materiale dominowały gatunki Thrips physapus, Thrips trehernei, Thrips validus i Frankliniella intonsa. Największą różnorodnościa gatunkową wciornastków charakteryzowały się gatunki roślin: Hieracium umbellatum, Matricaria perforata, Taraxacum officinale, Erigeron strigosus. W wyniku przeprowadzonych badań można stwierdzić, iż środowisko miejskie jest dość bogate pod względem różnorodności gatunkowej wciornastków. Odłowiona liczba gatunków wskazuje na ich tolerancję na umiarkowanie niekorzystne warunki panujace w mieście. Najważniejszym czynnikiem wpływającym na liczbę zebranych gatunków jest bogactwo gatunkowe roślin. Stanowiska o różnym stopniu przekształcenia różniły się zarówno składem gatunkowym, jak i liczebnościa stwierdzonych wciornastków.

[Sęczkowska, Gawarecka 1967; Sęczkowska 1974]. The research was conducted in ruderal communities in areas which are developed at present. In 2001-2003, studies were carried out in various plant communities both in the centre and on the outskirts of Lublin [Czepiel 2004; Czepiel-Mil 2006, 2007; Czepiel-Mil, Kowalczyk-Pecka 2011].

Other towns in which research on thrips was conducted were Puławy [Lubiarz 2011] and Kraków [Pobożniak et al. 2008; Pobożniak, Sobolewska 2011a, b; Pobożniak, Gaborska 2011].

The aim of this paper was to investigate the species composition of the thrips collected from the Asteraceae family from sites of different levels of anthropopressure in Lublin.

An ecologic and faunistic analysis will make it possible to distinguish biotopes of significant natural value. Future protection of these sites will allow numerous thrips species to survive. 


\section{MATERIAL AND STUDY METHODS}

Research was conducted on 15 selected sites, located in various parts of the city, in the years 2001-2003, from April to October. At each site, thrips were collected in a biannual cycle. At some sites research was carried out in 2001-2002, at others in 2002-2003 and only at green park sites in the years 2002-2003. The insects were gathered at fortnightly intervals by shaking off flowers and leaves of 34 species of the Asteraceae family Table 1). The thrips were collected using the so-called small bag method and selected in a laboratory.

The designated sites were classified as: semi-natural - with low anthropopressure, situated on the outskirts of the city (fresh, dry and moist meadows and xerothermic communities) and anthropogenic - ruderal communities (dominant in an urbanised landscape) and park greenery. The latter were located in the city centre or in the vicinity of housing estates as well as motorways and railroads. Using Sukopp's hemoroby scale, referring to the degree of habitat transformation, selected sites were classified as the mezohemerobic (with semi-natural vegetation) and euhemerobic biotope (with ruderal and segetal vegetation) [Jackowiak 1990]. Euhemerobic biotopes were further divided into $\alpha$-euhemerobic (roadsides, railway embankments), $\beta$-euhemerobic (next to old buildings and fences) and $y$-euhemerobic (field, garden areas) [Chmiel 1993] (Fig. 1). Thysanoptera species were identified using the keys of Schliephake and Klimt [1979] and of zur Strassen [2003]. The terminology used is in accordance with Poland's thrips list [Kucharczyk 2007]. Field plant identification was carried out using Rutkowski's [1998] work. Names of vascular plants were based on Rutkowski's key [1998].

\section{RESULTS AND DISCUSSION}

The thrips were collected on 34 plant species of the Asteraceae family. As a result of shaking off flowering plants 12,592 specimens of Thysanoptera were gathered, belonging to 36 species of the Aeolothripidae, Thripidae and Phlaeothripidae families (Table 1). That represents c. 17 per cent of the fauna of this insect group in Poland.

The qualitative contribution of individual thrips species on the collected herbaceous plants species was not even, with Hieracium umbellatum, Matricaria perforata, Taraxacum officinale, Erigeron strigosus characterised by the greatest diversity of thrips species. The most specimens were found on yellow flowers of $\mathrm{T}$. officinale, $H$. umbellatum and Sonchus arvensis. This colour is the most attractive to thrips [Hoddle et al. 2002; Blumthal et al. 2005]. Pobożniak confirms this fact in her studies [Pobożniak, Gaborska 2011], in which those insects frequently occurred on S. arvensis, Solidago canadensis, T. officinale, Leontodon autumnalis, Crepis biennis and Chrysanthem leucantheum.

Only one thrips species was found on Tanacetum vulgare (15 exx) and Bellis perennis (1 exx).

The specimens dominant in the whole sample were: Thrips physapus (3639 exx), Thrips trehernei (2618 exx), Thrips validus (2328 exx) and Frankliniella intonsa (1245 exx). Less numerous (408862 exx) were: Thrips flavus, Thrips fuscipennis, Thrips major and Thrips tabaci.

The 36 collected taxons represented two throphic thrips groups zoophagous and phytophagous species. Only Aeolothrips intermedius from the Aeolothripidae family (58 exx) was classified as zoophagous. The species occurs where aphids and thrips larvae,

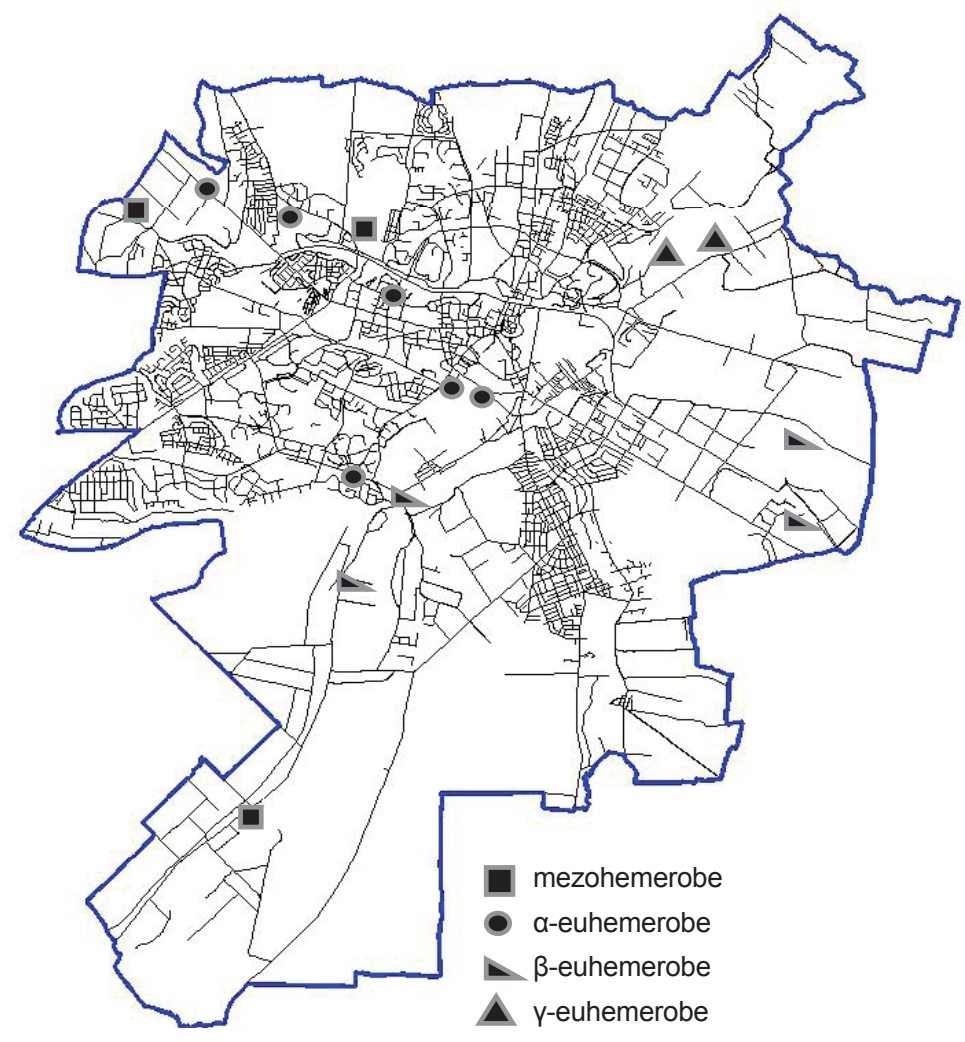

Fig. 1. Distribution of studied sites of different hemeroby levels in Lublin. Figure for: geoportal.lublin.eu 
Table 1. Thysanoptera collected by shaking off some species of plants of the Asteraceae family on selected sites

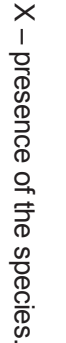

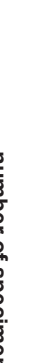

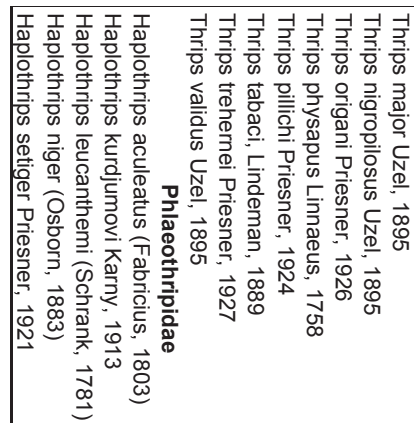
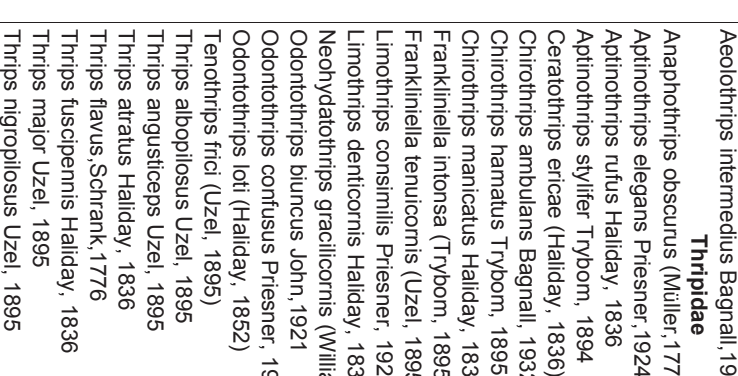

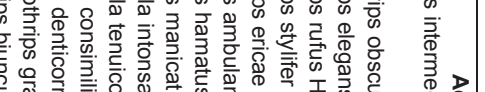

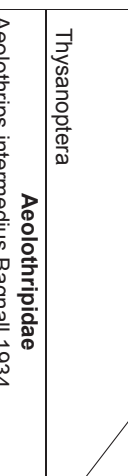

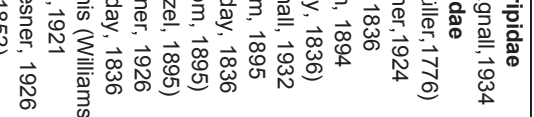
$\stackrel{\overrightarrow{0}}{\overrightarrow{0}}$

Leontodon autumnalis Leontodon hispidus

Aster tripolium

Centaurea scabiosa

Centaurea jacea

Centaurea stoebe

Cichorium intybus Picris hieracioides

Hieracium cymosum Hieracium lactucella

Hieracium umbellatum Hieracium murorum Tragopogon pratensis

Matricaria perforata

Sonchus arvensis

Taraxacum officinale

Tanacetum vulgare

Tussilago farfara

Solidago canadensis

Solidago gigantea Achillea millefolium

Carduus crispus

Cirsium arvense

Cirsium palustre

Cirsium rivulare Hypochoeris glabra

Crepis biennis

Erigeron strigosus Eupatorium cannabinum

Bellis perennis

Bidens cernua

Senecio jacobaea

Chamomilla recutita Chrysanthemum vulgare number of specimens 
which it feeds on, are found [Sęczkowska 1956]. Pollen is not sufficient for this predator to develop. When it eats diversified food, its development cycle is shorter and it has numerous offspring. This species definitely reduces the population of e.g. Thrips tabaci (feeding on leeks, onions, cabbage) [Trdan et al. 2005].

The phytophagous group comprised: 14 herbicolous species (feeding on all plant parts), 11 floricolous species (occurring in flowers), 10 graminicolous species (feeding on inflorescence, grass and sedge leaves) and 1 foliicolous species (connected with leaves of herb plants, trees and shrubs) (Table 2).

The most richly represented group was herbicolous polyphagous thrips. These species are able to survive in various ecosystems, in which other insects may be endangered due to environment alternations. Dominant among them were the common species: T. physapus, T. trehernei, T. validus and F. intonsa. Pobożniak and Sobolewska's [2011a] studies confirm frequent occurrence of $T$. trehernei as the main dominant species collected from Arnica montana (Asteraceae) and $T$. validus from $S$. arvensis.

Frankliniella intonsa is a polyphagous species whose main food is pollen [Kirk 2008]. As Raspudić et al. [2009] report, apart from Thrips tabaci, it is the thrips that most frequently occurs on the Asteraceae family flowers.

The collected insects also comprised 10 species obtained on monocotyledonous plants: Anaphothrips obscurus, Aptinothrips elegans, A. rufus, A. stylifer, Chirothrips ambulans, Ch. hamatus, Ch. manicatus, Limothrips consimilis, L. denticornis and Haplothrips aculeatus. Among the above-mentioned species, A. elegans is a thermophilous stenotopic thrips. Such species of a limited spectrum of tolerance to various environment factors represent the smallest group in a city [Winiarska 1999].

Moreover, six monofagous species were collected. The most numerous among them was Haplothrips leucanthemi (17 exx.), a common meadow species, found exclusively on $M$. perforata, and occurring on Leucanthemum plants. The remaining species are Chrothrips ambulans (Poa pratensis), Limothrips consimilis (Bromus sp.), Thrips albopilosus (Humulus lupulus), T. origami (Origanum vulgare) and Ceratothrips ericae (Calluna sp.). The abovementioned species play a very important role in pollinating heather plants [Fayos, Goldarazena 2008].

The greatest number of mature specimens (imago) was gathered from plants in May, July and August. In June, July and September, there were quite a lot of larvae.

Twenty-five species of Thysanoptera were collected on mezohemerobic sites. The number of plants gathered there constituted 27 per cent of all the thrips collected. This biotope comprises semi-natural sites exposed to low anthropogenic pressure. They are situated on the city outskirts and are characterised by lush vegetation. The samples collected on these sites were affected by the species composition of plants of the Asteraceae family. Thrips physapus was the most numerous species and Chirothrips hamatus ( 1 exx) was found only in this biotope. This is a hygrophilous species connected with grass plants so it was only accidentally gathered from $T$. officinale (Table 2).

On euhemerobic sites 35 species were caught, with the most collected on $\alpha$ - (31 species), fewer on $\beta$ - (28 species) and the fewest on yeuhemorobic ( 21 species) ones. Six sites were of an $\alpha$-euhemerobic type. Three of them were located on the outskirts, in the northwestern and western parts of the city, where 3999 specimens belonging to 29 species were collected. This represented 32 per cent of all the specimens gathered. The remaining three sites were located in city green areas, where thrips fauna was poor. Only 18 species and 1621 specimens were collected. This represented only 13 per cent of all collected specimens. Mowing the lawns, walking on the grass as well as environment pollution were the factors contributing to the reduction in the number of species and the number of insects [Eremeeva, Sushchev 2005]. $\beta$-euhemerobic sites were located on the outskirts of the city, in its southeastern and southern parts. The studied area was covered by diversified vegetation of ruderal and grass character, with the dominance of $T$. vulgare, C. biennis and Cirsium arvense. Twentyeight thrips species were collected there, with $T$. physapus, $T$. validus, $T$. trehernei and $F$. intonsa being the dominants. Pobożniak and Gaborska [2011] reported the occurrence of the above-mentioned thrips of $C$. biennis, with $T$. trehernei being the dominant. Whereas in Lublin, T. physapus was the most numerous on C. biennis and Cirsium arvense, in all the biotopes studied.

The poorest thrips fauna, constituting only about 10 per cent of all the specimens gathered, was characteristic of $y$-euhemerobic sites with ruderal vegetation, located in the vicinity of factories in the eastern part of the city. The following polyphagous species were numerous there: $T$. trehernei, T. physapus, T. validus and $F$. intonsa. In urban environment, synanthropic plants constitute more than a half of food spectrum for such polyphagous species [Eremeeva, Sushchev 2005].

The above data show that the presence of diversified vegetation, which is the staple food for insects, clearly affects their species composition and number. Furthermore, both the kind of host plant and the kind of pollen influence the number of offspring [Ugine et al. 2006]. An endangered plant species leads to the degradation of the entire habitat, causing a fall in the number of so far non-endangered insects [Connor, Hafernik 2002]. Urbanisation destroys natural plant-insect interactions [Perre, Loyola 2011].

Due to anthropopressure, the species that can remain the most numerous in a city are common ones, for example, F. intonsa and Thrips tabaci that accumulate heavy metals and are tolerant to air pollution [Vasiliu-Oromulu et al. 2009].

\section{SUMMARY}

During the 3-year study conducted in various plant communities in Lublin 12,592, Thysanoptera specimens belonging to 36 species were collected on plants from the Asteraceae family. The research conducted suggests that urban environment is characterised by quite considerable thrips species diversity. The obtained number of species indicates their tolerance to moderately adverse conditions in the city.

The most important factor affecting the number of the species collected is the diversity of plant species. Flowers satisfy their feeding requirements. Thrips use nectar, pollen and cell's content of various parts of the flower.

The acquired results show that in areas located far away from heavy traffic and in which there are fewer buildings (mezohemorobic and part of $\alpha$-hemerobic sites), the number of collected insects both in terms of quantity and species is similar. Diversified vegetation there constitutes the staple food for thrips. Such sites are scarce in the centre of the city.

Due to poor vegetation on sites more affected by anthropopressure, the insects are considerably less numerous, both in terms of species and numbers. The areas turn into wasteland and insects gradually withdraw from the sites they previously occupied. 
Table 2. Thysanoptera collected by shaking off some plant species of the Asteraceae family in the studied biotopes

\begin{tabular}{|c|c|c|c|c|c|c|c|c|}
\hline \multirow[b]{2}{*}{ L.p. } & \multirow[b]{2}{*}{ Thysanoptera } & \multicolumn{5}{|c|}{ Degree of hemeroby } & \multirow[b]{2}{*}{ 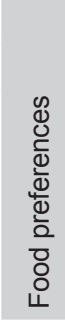 } & \multirow[b]{2}{*}{ 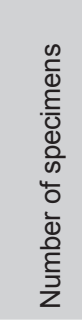 } \\
\hline & & 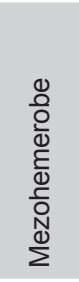 & Green park & 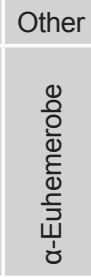 & 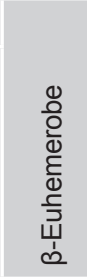 & $\begin{array}{l}0 \\
\stackrel{0}{0} \\
\frac{0}{\Phi} \\
\frac{\varepsilon}{0} \\
\frac{\varrho}{5} \\
\stackrel{1}{>}\end{array}$ & & \\
\hline & \multicolumn{8}{|c|}{ Aeolothripidae } \\
\hline \multirow[t]{2}{*}{1.} & Aeolothrips intermedius Bagnall,1934 & 36 & 2 & 10 & 7 & 3 & z & 58 \\
\hline & \multicolumn{8}{|c|}{ Thripidae } \\
\hline 2. & Anaphothrips obscurus Müller,1776 & 1 & 4 & 3 & & 1 & $g$ & 9 \\
\hline 3. & Aptinothrips elegans Priesner, 1924 & 3 & 1 & 3 & & & g & 7 \\
\hline 4. & Aptinothrips rufus Haliday, 1836 & & 1 & 4 & 4 & & g & 9 \\
\hline 5. & Aptinothrips stylifer Trybom, 1894 & & & & 2 & & g & 2 \\
\hline 6. & Ceratothrips ericae Haliday, 1836 & & & & 1 & & $\mathrm{fl}$ & 1 \\
\hline 7. & Chirothrips ambulans Bagnall, 1932 & 2 & 1 & 3 & 3 & 1 & g & 10 \\
\hline 8. & Chirothrips hamatus Trybom, 1895 & 1 & & & & & g & 1 \\
\hline 9. & Chirothrips manicatus Haliday, 1836 & 12 & 1 & 14 & 3 & 7 & $g$ & 37 \\
\hline 10. & Frankliniella intonsa Trybom, 1895 & 501 & 111 & 174 & 376 & 83 & $\mathrm{~h}$ & 1245 \\
\hline 11. & Frankliniella tenuicornis Uzel, 1895 & 1 & & 2 & 1 & & $\mathrm{~h}$ & 4 \\
\hline 12. & Limothrips consimilis Priesner, 1926 & 2 & & 1 & 1 & 2 & g & 6 \\
\hline 13. & Limothrips denticornis Haliday, 1836 & 1 & 1 & & & & g & 2 \\
\hline 14. & Neohydatothrips gracilicornis Williams, 1916 & & & 1 & 2 & & $\mathrm{fl}$ & 3 \\
\hline 15. & Odontothrips biuncus John, 1921 & & & 1 & & & $\mathrm{fl}$ & 1 \\
\hline 16. & Odontothrips confusus Priesner, 1926 & 2 & & 2 & & 3 & $\mathrm{fl}$ & 7 \\
\hline 17. & Odontothrips loti Haliday, 1852 & 2 & & 4 & 3 & & $\mathrm{~h}$ & 9 \\
\hline 18. & Tenothrips frici Uzel, 1895 & & 2 & 2 & 1 & 2 & $\mathrm{~h}$ & 7 \\
\hline 19. & Thrips albopilosus Uzel, 1895 & & & 2 & 1 & & $\mathrm{fl}$ & 3 \\
\hline 20. & Thrips angusticeps Uzel, 1895 & & & 7 & & & $\mathrm{~h}$ & 7 \\
\hline 21. & Thrips atratus Haliday, 1836 & 13 & 6 & 16 & 12 & 12 & $\mathrm{~h}$ & 59 \\
\hline 22. & Thrips flavus,Schrank,1776 & 88 & 18 & 145 & 155 & 61 & $\mathrm{~h}$ & 467 \\
\hline 23. & Thrips fuscipennis Haliday, 1836 & 123 & 60 & 102 & 79 & 44 & $\mathrm{~h}$ & 408 \\
\hline 24. & Thrips major Uzel, 1895 & 96 & 114 & 131 & 89 & 194 & $\mathrm{~h}$ & 624 \\
\hline 25. & Thrips nigropilosus Uzel, 1895 & & & 2 & 3 & 4 & $\mathrm{~h}$ & 9 \\
\hline 26. & Thrips origani Priesner, 1926 & 1 & & & 1 & & $\mathrm{fl}$ & 2 \\
\hline 27. & Thrips physapus Linnaeus, 1758 & 1336 & 418 & 1084 & 570 & 231 & $\mathrm{~h}$ & 3639 \\
\hline 28. & Thrips pillichi Priesner, 1924 & 16 & & 4 & 23 & 8 & $\mathrm{fl}$ & 51 \\
\hline 29. & Thrips tabaci, Lindeman, 1889 & 186 & 22 & 280 & 203 & 171 & $\mathrm{~h}$ & 862 \\
\hline 30. & Thrips trehernei Priesner, 1927 & 334 & 653 & 1068 & 299 & 264 & $\mathrm{~h}$ & 2618 \\
\hline \multirow[t]{2}{*}{31.} & Thrips validus Uzel, 1895 & 608 & 205 & 900 & 525 & 90 & $\mathrm{fl}$ & 2328 \\
\hline & Phlaeothripidae & & & & & & & \\
\hline 32. & Haplothrips aculeatus Fabricius, 1803 & 5 & & 5 & 3 & 1 & g & 14 \\
\hline 33. & Haplothrips kurdjumovi Karny, 1913 & & & 27 & & & fo & 27 \\
\hline 34. & Haplothrips leucanthemi Schrank, 1781 & & & & 15 & 2 & $\mathrm{fl}$ & 17 \\
\hline 35. & Haplothrips niger Osborn, 1883 & 2 & 1 & & 21 & & $\mathrm{fl}$ & 24 \\
\hline \multirow[t]{3}{*}{36.} & Haplothrips setiger Priesner, 1921 & 2 & & 2 & 7 & 4 & $\mathrm{~h}$ & 15 \\
\hline & Number of specimens & 3374 & 1621 & 3999 & 2410 & 1188 & - & 12592 \\
\hline & Number of species & 25 & 18 & 29 & 28 & 21 & - & \\
\hline
\end{tabular}

h, herbicolous; fl, floricolous; g, graminicolous; fo, foliicolous; z, zoophagous. 


\section{REFERENCES}

BLUMTHAL, M, CLOYD, R, SPOMER, L, WARNOCK, D 2005 Flower color preferences of western flower thrips. HortTechnology 15, vol. 4, pp. 846-853.

CHMIEL, J 1993, Flora roślin naczyniowych wschodniej części Pojezierza Gnieźnieńskiego i jej antropogeniczne przeobrażenia w wieku XIX i XX. Część I. Prace Zakładu Taksonomii Roślin UAM w Poznaniu, Wyd. Sorus, Poznań.

CONNOR, EF, HAFERNIK, J 2002, Insect conservation in an urban biodiversity hotspot: the San Francisco Bay Area. Journal of Insect Conservation, vol. 6, pp. 247-259.

CZEPIEL, K 2004, Thrips (Thysanoptera, Insecta) collected in wooded areas of the city of Lublin (south-eastern Poland). Acta Phytopathologica et Entomologica Hungarica vol. 39, 1-3, pp. 271-279.

CZEPIEL-MIL, K 2006, Rzadkie dla fauny Polski gatunki wciornastków (Thysanoptera) stwierdzone w Lublinie. Wiadomości Entomologiczne, 25, Suppl. 2, pp. 59-64, Poznań.

CZEPIEL -MIL, K 2007, Thrips (Thysanoptera, Insecta) recorded from the selected plant species of the Fabaceae family in the city of Lublin. Annales UMCS, Lublin, sec. C, vol. 62, pp. 37-46.

CZEPIEL-MIL, K, KOWALCZYK-PECKA, D 2011, Próba oceny wpływu polutantów w urbicenozach na podstawie obecności wciornastków (Insecta: Thysanoptera) zebranych w Lublinie. Ochrona środowiska i zasobów naturalnych. IOŚ-PIB, Warszawa, vol. 48, pp. 485-491.

EREMEEVA, NI, SUSHCHEV, DV 2005, Structural changes in the fauna of pollinating insects in urban landscapes. Russian Journal of Ecology, 36, vol. 4, pp. 259-265.

FAYOS, P, GOLDARAZENA, A 2008, The role of thrips in pollination of Arctostaphyllos Uva-Ursi. International Journal of Plant Sciences 169, vol. 6, pp. 776-781.

HODDLE, M, ROBINSON, L, MORGAN, D 2002, Attraction of thrips (Thysanoptera: Thripidae and Aeolothripidae) to colored sticky cards in a California avocado orchard. Crop Protection vol. 21, pp. 383-388.

JACKOWIAK, B 1990, Antropogeniczne przemiany flory roślin naczyniowych Poznania. Wyd. Naukowe UAM, Poznań, p. 232.

KIRK, WDJ 2008, Pollen-feeding and host specificity and fecundity of flower thrips (Thysanoptera). Ecological Entomology 10, vol. 3, pp. 281-289.

KUCHARCZYK, H 2004, Wciornastki (Insecta: Thysanoptera) jako element monitoringu ekologicznego w Puszczy Białowieskiej. Leśne Prace Badawcze vol. 3, pp. 85-94.

KUCHARCZYK, H 2007, Wciornastki (Thysanoptera) Polski, Fauna Polski W. Bogdanowicz (red.), Wyd. IŻ PAN, Warszawa.

LUBIARZ, M 2011, Thrips (Thysanoptera) inhabiting Quercus robur $L$. in the town landscape of Puławy and the natural landscape of Poleski National Park. Urban Fauna. Studies of animal biology, ecology and conservation in European cities. Bydgoszcz 2011, pp. 161-170.

PERRE, P, LOYOLA, RD 2011, Insects on urban plants: contrasting the flower head feeding assemblages on native and exotic hosts. Urban Ecosystems, vol. 14, pp. 711-722.

POBOŻNIAK, M, BISAGA, A, BUSSLER, M 2008, Atrakcyjność kwiatów drzew i krzewów dla wciornastków Thysanoptera w Ogrodzie Botanicznym w Krakowie. Fauna Miast. Ochronić różnorodność biotyczną w miastach. Bydgoszcz 2008, pp. 373-382.
POBOŻNIAK, M, GABORSKA, M 2011, Thrips species (Thysanoptera) occurring on characteristic and associated plant of selected plant communities on Nowa Huta meadows. Urban Fauna. Studies of animal biology, ecology and conservation in European cities. Bydgoszcz 2011, pp. 181-191.

POBOŻNIAK, M, SOBOLEWSKA, A 2011a, Biodiversity of thrips (Thysanoptera) in flowering herbs in Cracow Region of Poland. Journal of Plant Protection Research, 51, vol. 4, pp. 395-398.

POBOŻNIAK, M, SOBOLEWSKA, A 2011b, Thrips (Thysanoptera) species infesting herbaceous plants in Botanical Garden in Kraków (Poland). Urban Fauna. Studies of animal biology, ecology and conservation in European cities. Bydgoszcz 2011:, pp. 171-179.

RASPUDIĆ, E, IVEZIĆ, M, BRMEŽ, M, TRDAN, S 2009, Distribution of Thysanoptera species and their host plants in Croatia. Acta Aagriculturae Slovenica, vol. 93-3, pp. 275-283.

RUTKOWSKI, L 1998, Klucz do oznaczania roślin naczyniowych Polski niżowej. Wyd. PWN, Warszawa, p. 812.

SCHLIEPHAKE, G, KLIMT, K 1979, Thysanoptera Fransenflügler. Gustav Fischer Verlag, Jena, pp. 71-477.

SĘCZKOWSKA, K 1956, Badania nad przylżeńcami (Thysanoptera) stwierdzonymi na polach śródleśnych $w$ okolicach Wandzina. Annales UMCS, Lublin, Sec. C, vol. 11, pp. 183-221.

SĘCZKOWSKA, K, GAWARECKA, E 1967, Przylżeńce (Thysanoptera) roślin ruderalnych miasta Lublina. Annales UMCS, Lublin, Sec. C, vol. 22, pp. 107-115.

SĘCZKOWSKA, K 1974, Przylżeńce (Thysanoptera) występujące na roślinach szklarniowych. Annales UMCS, Lublin, Sec. C, vol. 29, pp. 187-193.

STRASSEN ZUR R, 2003, Die terebranten Thysanopteren Europas. Goecke \& Evers, Keltern, p. 277.

TRDAN, S, ANDJUS, L, RASPUDIĆ, E, KAĆ, M 2005, Distribution of Aeolothrips intermedius Bagnall (Thysanoptera:Aeolothripidae) and its potential prey Thysanoptera species on different cultivated host plants. Journal of Pest Science vol. 78, pp. 217-226.

UGINE, T, WRAIGHT, S, SANDERSON, J 2006, Influences of impatients pollen and exposure to Beauveria bassiana on bionomics of western flower thrips Frankliniella occidentalis. Biological Control vol. 37, pp. 186-195.

VASILIU-OROMULU, L, BĂRBUCEANU, D, BIANU, E 2009, Thysanoptera capability for biomonitoring of urban polluted green spaces (Insecta: Thysanoptera). Acta Entomologica Serbica, 14, vol. 2, pp. 185-194.

VASILIU-OROMULU, L, JENSER, G, BĂRBUCEANU, D 2008 , Frankliniella intonsa (Trybom, 1895) a very sensitive bioindicator for air pollution. Acta Phytopatologica et Entomologica Hungarica, 43, vol. 1, pp. 401-408.

WINIARSKA, G 1999, Owady w mieście - wybrane zagadnienia dotyczące znaczenia entomocenoz w ekosystemie miejskim, ich zagrożenia i problemów ochrony. Konferencja naukowa. "Ochrona owadów w Polsce u progu integracji z Unią Europejską", Kraków 23-24 września 1999, PTE, Poznań-Kraków, pp. 17-18.

ZAWIRSKA,I 1994, Wciornastki Thysanoptera. [w:] Diagnostyka szkodników roślin i ich wrogów naturalnych. SGGW, Warszawa, pp. 145-174. 